Pesq. Vet. Bras. 29(7):479-486, julho 2009

Review Article

\title{
Virulence factors of avian pathogenic Escherichia coli (APEC) ${ }^{1}$
}

\author{
Gerson Nakazato², Tatiana Amabile de Campos², Eliana Guedes Stehling², \\ Marcelo Brocchi ${ }^{2}$ and Wanderley Dias da Silveira ${ }^{2^{*}}$
}

\begin{abstract}
Nakazato G., Campos T.A., Stehling E.G., Brocchi M. \& Silveira W.D. 2009. Virulence factors of avian pathogenic Escherichia coli (APEC). Pesquisa Veterinária Brasileira 29(7):479-486. Departamento de Microbiologia e Imunologia, Instituto de Biologia, Universidade Estadual de Campinas (Unicamp), Cidade Universitária Zeferino Vaz s/n, Cx. Postal 6109, Barão Geraldo, Campinas, SP 13081-862, Brazil. E-mail: wds @ unicamp.br

Avian pathogenic Escherichia coli (APEC) strains cause a great diversity of diseases in birds and are responsible for great economic losses in the avian industry. To date, several studies have been carried out to better understand the APEC pathogenesis for a possible development of tools which could prevent the economics losses caused by these strains. This review discusses the virulence factors described do date to be expressed by these strains and the advances made to understand and identify virulence determinants present in APEC.
\end{abstract}

INDEX TERMS: APEC, avian Escherichia coli, virulence factors.

RESUMO.- [Fatores de virulência de Escherichia coli aviária patogênica (APEC).] Linhagens de Escherichia coli patogênicas para aves (APEC) causam uma grande diversidade de doenças em aves e são responsáveis por grandes prejuízos na indústria aviária. Nos últimos anos, vários estudos foram realizados para melhor entender a patogênese de linhagens APEC e para desenvolver ferramentas que podem prevenir as perdas econômicas causadas por estas linhagens. Esta revisão discute os fatores de virulência descritos nestas linhagens e os avanços realizados para entender e identificar os determinantes de virulência presentes em APEC.

TERMOS DE INDEXAÇÃO: APEC, Escherichia coli aviária, fatores de virulência.

\section{INTRODUCTION}

Escherichia coli is a rod-shaped, Gram-negative, facultative anaerobic bacterium that belongs to the Enterobacteriaceae family. E. coli typically colonizes the intestinal

\footnotetext{
${ }^{1}$ Received on November 11, 2008.

Accepted for publication on March 12, 2009.

2 Departamento de Microbiologia e Imunologia, Instituto de Biologia, Universidade Estadual de Campinas (Unicamp), Cidade Universitária Zeferino Vaz s/n, Cx. Postal 6109, Barão Geraldo, Campinas, SP 13081862, Brazil. *Corresponding author: wds@ unicamp.br
}

tract of humans (Drasar \& Hill, 1974), mammals and birds (Sokja, 1965). E. coli strains are usually found confined to the intestinal lumen, however in imunosuppressed hosts or when the gastrointestinal barriers are violated, these bacteria may cause infectious diseases (Nataro \& Kaper, 1998). Besides that, there are E. coli strains originated from adapted pathogenic clones that cause diseases among healthy animals (Nataro \& Kaper 1998).

Pathogenic E. coliare associated with intestinal (Nataro \& Kaper 1998) and extraintestinal human infections, like cystitis and pyelonephritis (Pechere 1985), septicemia (Orskov \& Orskov 1985) and meningitis in neonatal infants (Overall Jr 1970). Among other animals, pathogenic $E$. coli strains are also able to cause extraintestinal infections such as urinary infection (Wooley \& Blue 1976, Peeters 1994) and pyometra (Bjurstrom 1993) in dogs, and respiratory diseases in birds (Kaper et al. 2004). Currently, $E$. coli is considered to be the most significant example of gram-negative bacterium related with diverse diseases because of the different pathogenicity mechanisms and diseases that it is able to cause.

Diseases caused by avian pathogenic Escherichia coli (APEC)

Avian pathogenic E. coli strains are known as APEC (Dho-Moulin \& Fairbrother 1999) and are associated with 
diverse diseases, mainly extraintestinal, being responsible for great losses in the avian industry (Gross 1994). These diseases include: inflamation of the oviduct that results in decreased egg production and sporadic mortality in laying chickens and breeders, salpingitis that occurs when $E$. coli ascends the oviduct from the cloaca and extension into the body cavity through the compromised oviduct wall that leads to concurrent peritonitis (in: Barnes et al. 2003).

Colisepticemia is the most important disease caused by APEC strains. This infectious disease is considered to be initiated in the avian upper respiratory tract after a primary infection caused by different virus such as the Newcasttle virus, Infectious Bronchitis virus or Mycoplasma (Gross 1991). These primary infections would increase the avian susceptibility to APEC strains due to the decilliation of the upper respiratory cells and exposition to ammonia and contaminated dust existing in the growth animal environment would also favor the infectious process (Oyentude et al. 1978, Nagaraja et al. 1984). The respiratory infection caused by APEC strains, further to the virus infection, is considered to be the initial step for colisepticemia development in birds (Gross 1991). This infection is also referred to as aero sac disease and usually occurs among birds with 2 to 12 weeks of age, with the majority of the cases occurring among birds with 4 to 9 weeks of age with mortality reaching rates as high as $20 \%$ (Dho-Moulin \& Fairbrother 1999).

Death is the usual outcome of colisepticemia, but some birds may completely recover or recover with residual sequelae, as meningitis, panophthalmitis (swollen eye), osteoarthritis, synovitis and coligranuloma (Hjarres's Diseases) that is characterized by multiple granulomas in liver, cecum, duodenum and mesentery (in: Barnes et al. 2003).

In broilers and hatchers chickens, APEC strains also cause a syndrome named "swollen head syndrome". Lesions observed in this syndrome include gelatinous edema on the skin head and peri orbital tissues, and, in some cases, fibrous exudates in the subcutaneous head tissues and in the lachrymal glands (Pattison et al. 1989, Nunoya et al. 1991). Swollen head syndrome was first described in the South America (Morley \& Thomson 1984) and is considered to be an important avian disease in various countries including Brazil (Arns \& Hafez 1992). This syndrome has caused considerable losses in the avian industry because it is responsible for mortality of 3 to $4 \%$ of the birds and for reduction of 2 to $3 \%$ at the egg production (Morley \& Thomson 1984). Swollen head syndrome usually begins after an acute rhinitis caused by pneumovirus being followed by the invasion of the subcutaneous skin tissues by E.coli what causes the characteristic edema (Picault et al. 1987, Hafez \& Loehren 1990).

In broilers, APEC strains are also associated with cellulitis that is characterized by a necrotic dermatitis of the abdomen and thighs (Dho-Moulin \& Fairbrother 1999). Epidemiological data about this syndrome are not known but the lesions associated with cellulitis causes losses in the avian industry due to carcasses condemnation (Elfadil et al. 1996).

Some studies have showed positive relation among APEC and human extraintestinal pathogenic E. coli (ExPEC), mainly uropathogenic E. coli (UPEC) and newborn meningitis-causing E. coli (NMEC), sugesting that some APEC strains could be considered potential zoonotic agents (Ewers et al. 2007, Moulin-Schouleur et al. 2007, Johnson et al. 2008).

\section{Virulence factors of APEC strains}

Several investigations have added knowledge about the pathogenic mechanisms expressed by APEC strains (Dho-Moulin \& Fairbrother 1999). The virulence factors that have been described to be expressed by these strains include adhesins, toxins, iron uptake systems, and resistance to the host serum.

Adhesins. The bacterial adhesion to epithelium tissues is considered to be an important step for the establishment of the $E$. coli infection since it permits the bacterial linkage and maintenance in close contact to the host epithelial tissues (Moon 1990). Evidences that the adherence capacity of $E$. coli could be a virulence factor were initially proposed by Arp et al. (1980) which observed that a fimbriated and virulent strain was more persistent in the turkey trachea than an avirulent and afimbriated strain.

Among APEC strains, Type 1 fimbriae are related to the adhesion to the avian upper respiratory tract (Wooley et al. 1998). The adhesive properties of Type 1 fimbriae are inhibited by specific antiserum and by D-mannose, a carbohydrate that is its cellular receptor on the eurocariotic cell membrande. These characteristics are used for its characterization (Gyimah \& Panigraphy 1988). Pourbaskhsh et al. (1997) suggested that while Type 1 fimbriae is associated with the upper respiratory tract initial colonization $P$ fimbrial adhesin may be involved in the bacterial establishment in deeper avian organs. Wooley et al. (1998) also suggested that while Type 1 is necessary to initial colonization of the respiratory epithelium, additional factors like motility and colicin $\mathrm{V}$ production would be responsible by the persistence of the colonization and by the observed trachea lesions development. Marc et al. (1998) demonstrated, with the utilization of a fim- APEC mutant, that Type 1 fimbriae is not strictly required as a colonization factor during the avian colibacilosis development.

$P$ fimbrial adhesins were first described among $E$. coli strains associated with human urinary tract infections (UTI) (Kallenius et al. 1980) being also found among APEC strains (Achtman et al. 1983, Dozois et al. 1992). P fimbriae is encoded by the pap operon that is located in the bacterial chromosome (Latham \& Stamm 1994). papA gene encodes for the major structural protein (PapA), papl and papB are regulatory genes responsible for the phase variation process (Mol \& Oudega 1996). papE gene encodes for the fimbrial structural extremity, papG gene encodes for the adhesin, and papD, papH, papJ, papF 
and papK genes are responsible for the expression of proteins related to the hole integrity of the complex fimbrial assemblage (Mol \& Oudega 1996). The adhesive property of $P$ fimbriae is conferred by the terminal adhesin PapG that presents three molecular variants (I, II and III) (Hoschützky et al. 1989) that recognize different isoreceptors containing $\alpha$-D-galactosyl-(1-4)- $\beta$-galactopyranosil carbohydrate.

The role of $P$ fimbriae in the APEC pathogenicity has not been completed elucidated yet. Pourbakhsh et al. (1997) using in vivo studies, verified that $P$ fimbriae presented phase variation and suggested that these adhesins would not be important for the initial colonization of the upper respiratory tract, but it would be in the latter infection stages. Recently, Kariyawasam et al. (2006) demonstrated that the pap operon is present in a pathogenicity island of APEC strain APEC-O1. The authors suggested that the pap occurrence in horizontaly acquired genomic regions might be involved in the transformation of avirulent strains into virulent ones.

Curli fimbriae are thin and curly appendices found on the cell surface of Salmonella enterica and E. coli (Olsén et al. 1989), and are responsible for the bacterial linkage to proteins of the extracellular matrix (Collinson et al. 1993) and for bacterial survival in the external environment (Olsén et al. 1993). Curli fimbriaes are optimally expressed at $26^{\circ} \mathrm{C}$ during the growth in the stationary phase and in low osmolarity medium (Olsén et al. 1993). The genes responsible for curli fimbriae expression are encoded by two operons: csgBAC and csgDEFG. csgA gene encodes for the monomers structural subunits, named curlina while csgB gene encodes for a protein needed for curlina complex stability. The operon csgDEGF has it expression controlled by environmental factors like temperature, osmolarity, $\mathrm{pH}$, and other stress factors (La Ragione \& Woodward 2002). The curli fimbriae expression is also dependent of Rpos factor, an ó factor that controls the expression of several genes during the stationary phase of bacterial growth (Olsén et al. 1993). Curli related sequences have been widely found among APEC strains. Maurer et al. (1998) detected csgA gene in all APEC strains analyzed. The same curli-related sequence was found among $90 \%$ of the strains isolated by Knöbl (2001) from ostriches with respiratory disease and among $70 \%$ of strains analyzed by Campos et al. (2005). In this latter study, the authors detected csgA sequence in all APEC isolated from chickens with septicemia and in none of the $E$. coli strains isolated from the intestinal microbiota of chickens. However a study made by McPeake et al. (2005) demonstrated that the csgA gene was presented among all strains analyzed, isolated from chickens with septicemia and from healthy chickens.

Other adhesins identified among APEC strains comprised the AC/1 fimbriae and type 1-like fimbriae ( $\mathrm{La}$ Ragione \& Woodward 2002). The presence of fimbriae F17, Afa, Sfa, and Eae DNA-related sequences among APEC strains may indicate that these adhesins can be found on the cell surface of APEC (Stordeur et al. 2002, Campos et al. 2005, McPeake et al. 2005) and could also be implicated in the pathogenesis presented by these strains.

Temperature-sensitive hemagglutinin. The temperature-sensitive hemagglutinin (TSH) is a protein expressed by APEC strains that present chicken erythrocytes hemagglutination activity at $26^{\circ} \mathrm{C}$ and have this activity repressed at $42^{\circ} \mathrm{C}$ (Provence \& Curtiss III 1994). TSH is a serine-protease autotransporter protein that is synthesized as a $140 \mathrm{KDa}$ precursor, and is cleaved in two subunits in the bacterial periplasm: one subunit, with $33 \mathrm{KDa}$, that remains inserted in the outer membrane and functions like a passenger domain; and other subunit with $106 \mathrm{KDa}$ that is secreted to extracellular environment. The $106 \mathrm{KDa}$ subunit remains temporally in the outer membrane and mediates the bacterial adhesion during the initial stages of the infection (Stathopoulos et al. 1999). After its secretion, the $106 \mathrm{KDa}$ sub-unit probably presents a characteristic proteolytic activity, that renders the TSH protein a bifunctional protein, with adhesive and proteolytic activities (Kostakioti \& Stathopoulos 2004).

TSH is encoded by the tsh gene (Provence \& Curtiss III 1994). This gene is located in high molecular weigh plasmids (Dozois et al. 2000, Stehling et al. 2003, Johnson et al. 2006), mainly in ColV plasmids and is frequently found among APEC strains. Maurer et al. (1998) detected the tsh gene among $46 \%$ of the studied APEC strains and in none of the commensal isolates. Campos et al. (2005) demonstrated that the tsh gene was found among 25 and $50 \%$ APEC strains isolated from chickens with septicemia and swollen head syndrome, respectively, and in only $6 \%$ of the commensal strains. Because the association of the tsh gene with APEC pathogenicity, Ewers et al (2004) proposed its utilization as a molecular marker to detect APEC strains.

Iron acquisition systems. APEC strains survive and growth in environments with low iron availability, mainly inside the host, because the expression of iron acquisition systems (Dho \& Lafont 1984). The bacterial iron acquisition mechanisms include the production of siderophores that act as ion chelants in the host (Williams \& Griffiths 1992). Two types of siderophores are known: fenolates and hidroxamate. Aerobactin is a hidroxamate siderophore that is encoded by a plasmid operon (Gibson \& Magrath 1969, Williams 1979). This siderophore is also found among fungi, enteroinvasive E. coli and APEC strains (Dho \& Lafont 1984, Waters \& Crosa 1991).

Dho \& Lafont (1984) observed a positive correlation between the low iron concentration, APEC growth ability and the lethality capacity to one-day old chickens observed in these strains. Also, Linggood et al. (1987), Dozois et al. (1992), Emery et al. (1992) and Silveira et al. (2002a) demonstrated that pathogenic APEC strains expressed iron uptake systems while non pathogenic strains did not express. The yersiniabactin system (fyuA and irp-2 genes) (Pelludat et al. 1998, Schubert et al. 1998, Karch et al. 
1999) were found in higher frequencies among APEC strains (Gophna et al. 2001, JanBen et al. 2001). Genes related with another iron acquisition systems, like iucA and fepC genes, were also found among APEC strains (Okeke et al. 2004). A recent work realized by our research group (Campos et al. 2005) showed a high frequency of iron uptake related genes among pathogenic avian $E$. coli strains.

Recently, a sitABCDE Salmonella enterica homologue system were identified in an APEC strain (Sabri et al. 2006, Sabri et al. 2008). In this strain, the sitABCDE is an iron and manganese transporter system that, in combination with other iron uptake systems, can contributes to iron acquisition and to the oxidative stress bacterial survival (Sabri et al. 2006). Among APEC strains, iron acquisition systems can be encoded by plasmid genes (Johnson et al. 2006, Sabri et al. 2006) or by chromosomal pathogenicity islands (Kariyawasam et al. 2006).

Colicins. These are proteins expressed by E. coli that inhibit the bacterial growth from the same or related species. Colicins are compounded by two subunits: one that provokes bacterial cell lesions and other that protects the bacterium against their own colicins (Hardy et al. 1975). Colicins can be encoded by genes located in plasmids. Because of this, they are frequently called Col plasmids. Works establishing colicin expression by APEC strains indicated that colicins la, Ib, E1, E2, E3, I, K, B and V are the most prevalent ones among these bacterial strains (Fantinatti et al. 1994, Silveira et al. 2002a).

The majority of APEC strains have colicin V plasmids (Wray \& Woodward 1997). Theses plasmids also contain other pathogenicity related genes (Valvano et al. 1992, Johnson et al. 2003). Mutations at ColV plasmids demonstrated decreasing of the virulence, suggesting that some genes linked to ColV plasmids are involved in the establishment of avian infection (Skyberg et al. 2008).

Capsule. Some E. coli strains have an $\mathrm{N}$-acetyl muramic acid capsule on their cell surface that interacts with the classical complement pathway conferring immune resistance to the bacteria and that induces the immune resistance (Jann \& Jann 1977).

$\mathrm{K} 1$ capsular antigen is frequently associated to APEC strains belonging to serogroups $\mathrm{O} 1, \mathrm{O} 2$ and to non typable strains (Gross 1991). Pourbakhsh et al. (1997) demonstrated the three APEC strains expressing capsule $\mathrm{K} 1$ were more resistance to the serum bactericidal effects than APEC strains that expressed other $\mathrm{K}$ antigens.

Serum resistance. The bacterial resistance to the complement, mediated by bacterial surface structures like LPS, capsule, Col V colicin, and outer membrane proteins, have been associated with APEC strains (Gross 1991, Fantinatti et al. 1994, Ngeleka et al. 1996, Lynne et a. 2007).

Pfaff-McDonough et al. (2000) suggested that the Iss factor (increased serum survival) is associated with APEC pathogenicity since the iss gene have been found more frequently among pathogenic than non pathogenic strains, despite of serotype, avian species and lesion origin. The occurrence of iss gene in conjugative Col $\mathrm{V}$ plasmid (Johnson et al. 2002, Mellata et al. 2003) can suggest the relationship of Iss factor to the APEC pathogenicity. Besides the role of Iss, Mellata et al. (2003) suggested that the $\mathrm{O} 78$ polysaccharide and the $\mathrm{K} 1$ capsule are virulence factors that increase the bacterial serum survival.

Toxins. Some APEC strains are able to produce toxins like labile temperature (LT) and stable temperature (ST) enterotoxins (Smith \& Gyles 1969), and verotoxins known as Shiga-toxins (Stx) (O'Brien et al. 1977; O'Brien et al. 1982, Emery et al. 1992, Parreira \& Yano 1998, Fantinatti et al. 1994, Blanco et al. 1997).

APEC strains cytotoxic activity to Vero cells was observed by Fantinatti et al. (1994) and by Parreira \& Yano (1998). Parreira \& Gyles (2002) identified a Stx- gene among $E$. coli strains isolated from chickens suffering from cellulitis, septicemia, and swollen head syndrome and from sick turkeys. These same authors (Parreira \& Gyles 2003) described a vacuolating toxin to be expressed by an APEC strain. This toxin is encoded by the vat gene that belongs to a pathogenicity island and was latter found to be expressed by another APEC strains (Ewers et al. 2004, Ewers et al. 2005).

Other virulence factors. Other virulence factors found among APEC strains include pathogenicity islands (Parreira \& Gyles 2003, Kariyawasam et al. 2006, Kariyawasam et al. 2008) and the locus of enterocyte effacement (LEE) (Foster et al. 1998, Pennycott et al. 1998, La Ragione et al. 2002). Rodriguez-Siek et al. (2005) showed that E. coli strains isolates obtained from human UTI and avian colibacilosis could have substantial overlap in terms of serogroups, phylogenetic groups and virulence genotypes, including plasmid-DNA-related sequences, adhesion, iron uptake, protectins and toxins-related sequences.

The Congo red linkage capacity in agar medium has been observed among APEC strains. Some authors have purposed the utilization of this characteristic as virulence marker to APEC strains (Berkhoff \& Vinal 1986, Corbett et al. 1987).

\section{New approaches for virulence determinants detection}

Modern molecular biology techniques such as the in vivo expression (Mahan et al., 1993), selective capture of transcript sequences - SCOTS (Graham \& Clarck- Curtiss 1999), fluorescence differential induction (Valdivia \& Falkow 1996) and signature tagged transposon mutagenesis - STM (Shea et al. 1996) have added knowledge to the bacterial pathogenicity because permit verify the gene expression during the infectious process. By the sequencing of cDNAs obtained from pathogen-specific transcripts sequences selection (SCOTS), Dozois et al. (2003) verified that transcripts related to adhesins, LPS synthesis, iron uptake systems, plasmid and phage sequences were expressed by $X^{7122}$ APEC strain during the infection process. Using the STM technology, Li et al. (2005) observed that LPS, iron uptake systems, and capsule are important virulence determinants associated with septicemia by APEC strains. 
Besides, these authors observed that genes encoding metabolic enzymes are required during the pathogenesis of avian colisepticemia process.

Some genomic comparison studies have demonstrated that APEC strains share virulence sequences with ExPEC isolated from humans. A subtractive hybridization analysis with two APEC strains and one E. coli K12 strain (Stocki et al. 2002) detected APEC specific DNA sequences presenting high homology with DNA sequences of $E$. coli O157:H7 and human ExPEC strains. Johnson et al. (2003) recovered strains from chicken retails products that presented virulence profiles, phylogenetic group background, and $\mathrm{O}$ antigens resembling those of humans ExPEC isolates and, recently, Johnson et al. (2007) obtained the DNA sequence of the genome of a APEC O1. It contained a 5,082,025-bp chromosome and four plasmids totaling 565,600 bp in size giving it a total genome size of $5,647,625 \mathrm{bp}$. Overall, APEC O1 shared the greatest nucleotide and protein similarities with strain UTI 89 (O18:K1:H7), isolated from a patient with uncomplicated cystitis followed by strain 536 (O6:K15:H31), isolated from a patient with a complicated UTI and strain CFT073 (O6:K2:H1), isolated from a patient with pyelonephritis.

A subtractive hybridization study performed with a human UTI E. coli and an avian colisepticemia strain demonstrated that both group of strains have virulence determinants in common such as the Type Three Secretion System (TTSS) and iron uptake systems but shared few virulence related sequences (Mokady et al. 2005). In this study it was observed that non-common virulence-related DNA sequences found in EXPEC and APEC strains were phenotypically associated with the same pathogenic process. The authors suggested that both groups of strains were using different factors with similar roles in the various stages of the infection: adhesion mediated by pilus, internalization by curli fibers, invasion, and persistence in the host by the iron uptake systems and by the evasion from the host immune system. Altogether, these studies suggest that since APEC and human ExPEC and diarrhegenic $E$. colimay encounter similar challenges when establishing infection, they could share similar virulence genes and capacities to cause disease, indicating that APEC could serve as a reservoir and source of virulence genes for human pathogenic E. coli such as ExPEC and diarrheogenic E. coli.

\section{Clonal relationship and pathogenic clone detection}

Molecular typing based in repetitive extragenic palimdromic amplification (REP) and Enterobacterial repetitive intergenic (ERIC) sequences analysis have been used to the clonal characterization of Enterobacteriaceae. The dispersive distribution of these repetitive DNA sequences in microbial organisms can be detected by using conserved primer in polymerase chain reaction (PCR) (Hulton et al. 1991, Versalovic et al. 1991). Moura et al. (2001) using REP-PCR and ERIC-PCR techniques suggested that there was not an association between the phenotype and genotype of APEC strains isolated from chickens in Londrina (Paraná, Brazil), based on the great phenotypic and genotypic variability presented by the studied strains. Brocchi et al. (2006) also found a high genomic diversity among APEC strains using REP-PCR, but these authors concluded that this technique is not efficient to differentiate among APEC pathogenic clones. A clonal diversity study with commensal avian E. coil strains and APEC strains performed by Silveira et al. (2002b), using ERIC-PCR, demonstrated a relationship between the pathogenicity and the clonal origin of APEC strains. These observations were also made by Brito et al. (2003) in APEC strains isolated from chickens with cellulitis.

White et al. (1993), using multilocus enzyme electrophoresis (MLEE), observed that APEC strains causing septicemia in turkeys belonged to a mixture of specialized pathogenic clones and non-pathogenic opportunist clones. Using the same technique, Ngeleka et al. (1996) demonstrated that APEC isolated from chickens with cellulitis belonged to the same clonal complex and had similar phenotypic and genotypic characteristics of APEC causing septicemia. In addition, Silveira et al. (2003) using the same technique also demonstrated that pathogenic clones are more similar one to another when compared with commensal strains suggesting a correlation between the genetic background and the pathogenic characteristics of the avian pathogenic E. coli strains.

Ewers et al. (2004), using pulsed field gel electrophoresis (PFGE), have verified the presence of a limited number of epidemic clones among APEC strains from different regions of Germany. However, the authors did not observe an association between virulence-related sequences and clonal clusters. Ewers et al. (2005) suggested that a horizontal gene transference of virulence genes could be responsible by the non association of virulence genes presence and pathogenic clonal clusters of APEC from Germany.

Altogether, these studies have demonstrated that APEC strains present a complex structure which could be responsible for the absence of a clear definition of pathotypes in these strains.

\section{CONCLUSION}

Although several advances have been made about the virulence factors of APEC strains, the exact role in the pathogenesis of these strains still remains unclear. It is apparent that APEC causes multi-factorial diseases, which involves host-pathogens interactions. Thus, molecular and biological characterization linked to appropriated animal models is needed to better understand the APEC pathogenesis.

\section{REFERENCES}

Achtman M., Mercer A., Kusecek B., Pohl A., Heuzenroeder M., Aaronson W., Sutton A. \& Silver R.P. 1983. Six widespread bacterial clones among Escherichia coli K1 isolates. Infect. Immun. 39:315-335. 
Arns C.W. \& Hafez H.M. 1992. Swollen head syndrome in poultry in Brazil. Proc. Western Poultry Disease Conference, Sacramento, USA, p.81-84.

Arp L.H. \& Jensen A.E. 1980. Piliation, hemagglutination, motility, and generation time of Escherichia coli that are virulent or avirulent of turkeys. Avian Dis. 24:153-161.

Barnes H.J, Vaillancourt J.P. \& Gross W.B. 2003. Newcastle disease, p.631-656. In: Ibid. (Ed.), Diseases of Poultry. 11th ed. Iowa State University Press, Ames.

Berkhoff H.A. \& Vinal A.C. 1986. Congo red medium to distinguish between invasive and non-invasive Escherichia coli for poultry. Avian Dis. 30:117-121.

Bjurstrom L. 1993. Aerobic bacteria occurring in the vagina of bitches with reproductive disorders. Acta Vet. Scand. 34:29-34.

Blanco J.E., Blanco M., Mora A. \& Blanco J. 1997. Production of toxins (enterotoxins, verotoxins and necrotoxins) and colicins by Escherichia coli strains isolated from septicemic and healthy chickens: relationship with in vivo pathogenicity. J. Clin. Microbiol. 35:2953-2957.

Brito B.G., Gaziri L. \& Vidotto M.C. 2003. Virulence factors and clonal relationships among Escherichia coli strains isolated from broiler chickens with cellulitis. Infect. Immun. 71:4175-4177.

Brocchi M., Ferreira A., Lancellotti M., Stehling E.G., Campos T.A., Nakazato G., Castro A.F.P. \& Silveira W.D. 2006. Typing of avian pathogenic Escherichia coli strains by REP-PCR. Pesq. Vet. Bras. 26:69-73.

Campos T.A., Stehling E.G., Ferreira A., Castro A.F.P., Brocchi M. \& Silveira W.D. 2005. Adhesion properties, fimbrial expression and PCRdetection of adhesin-related genes of avian Escherichia coli strains. Vet. Microbiol. 106:275-285.

Collinson S.K., Doig P.C., Doran J.L., Clouthier S., Trust T.J. \& Kay W.W. 1993. Thin, aggregative fimbriae mediate binding of Salmonella enteritidis to fibronectin. J. Bact. 175:12-18.

Corbett W.T., Berkhoff H.A. \& Vinal A.C. 1987. Epidemiological study of the relationship between Congo red binding Escherichia coli and avian colisepticemia. Can. J. Vet. Res. 51:312-315.

Dho M. \& Lafont J.P. 1984. Adhesive properties and iron uptake abilities in $E$. coli lethal and non-lethal for chicks. Avian Dis. 28:1016-1025.

Dho-Moulin M. \& Fairbrother J.M. 1999. Avian pathogenic Escherichia coli (APEC). Vet. Res. 30:299-316.

Dozois C.M., Fairbrother J.M., Harel J. \& Bossé M. 1992. pap- and pilrelated DNA sequences and other virulence determinants associated with Escherichia coli isolated from septicemic chickens and turkeys. Infect. Immun. 60:2648-2656.

Dozois C.M., Dho-Moulin M., Breé A., Fairbrother J.M., Desautels C. \& Curtiss III R. 2000. Relationship between the Tsh autotransporter and pathogenicity of avian Escherichia coli and localization and analysis of the Tsh genetic region. Infect. Immun. 68:4145-4154.

Dozois C.M., Daigle F. \& Curtiss III R. 2003. Identification of pathogenspecific and conserved genes expressed in vivo by an avian pathogenic Escherichia coli strain. Proc. Natl Acad. Sci. USA 100:247-252.

Drasar B.S. \& Hill M.J. 1974. Human Intestinal Flora. Academic Press, London, UK, p.36-43.

Elfadil A.A., Vaillancourt J.P., Meek A.H., Julian R.J. \& Gyles C.L. 1996. Description of cellulitis lesions and associations between cellulitis and other categories of condemnation. Avian Dis. 40:690-698.

Emery D.A., Nagaraja K.V., Shaw D.P., Newman J.A. \& White D.G. 1992. Virulence factors of Escherichia coli associated with colisepticemia in chicken and turkeys. Avian Dis. 36:504-511.

Ewers C., Janssen T., Kiessling S., Philipp H.C. \& Wieler L.H. 2004. Molecular epidemiology of avian pathogenic Escherichia coli (APEC) isolated from colisepticemia in poultry. Vet. Microbiol. 104:91-101.

Ewers C., Janssen T., Kiessling S., Phillip H.C. \& Wieler L.H. 2005. Rapid detection of virulence-associated genes in avian pathogenic
Escherichia coli by multiplex polymerase chain reaction. Avian Dis. 49:269-273.

Ewers C., Li G., Wilking H., Kiessling S., Alt K., Antáo E.M., Laturnus C., Diehl I., Glodde S., Homeier T., Böhnke U., Steinrück H., Philipp H.C. \& Wieler L.H. 2007. Avian pathogenic, uropathogenic, and newborn meningitis-causing Escherichia coli: how closely related are they? Int. J. Med. Microbiol. 297: 163-176.

Fantinatti F., Silveira W.D. \& Castro A.F.P. 1994. Characteristics associated with pathogenicity of avian septicaemic Escherichia coli strains. Vet. Microbiol. 41:75-86.

Foster G., Ross H.M., Pennycott T.W., Hopkins G.F. \& McLaren I.M. 1998. Isolation of Escherichia coli O86:K61 producing cyto-lethal distending toxin from wild birds of the finch family. Lett. Appl. Microbiol. 26:395-398

Gibson F. \& Magrath D.I. 1969. The isolation and characterization of a hydroxamic acid (aerobactin) formed by Aerobacter aerogenes 62-I. Biochim. Biophys. Acta. 152:175-184.

Gophna U., Oelschlaeger T.A., Hacker J. \& Ron E.Z. 2001. Yersinia $\mathrm{HPI}$ in septicemic Escherichia coli strains isolated from diverse hosts. FEMS Microbiol. Lett. 196:57-60.

Graham J.E. \& Clarck-Curtiss J.E. 1999. Identification of Mycobacterium tuberculosis RNAs synthesized in response to phagocytosis by human macrophages by selective capture of transcribed sequences (SCOTS). Proc. Natl Acad. Sci. 96:11554-11559.

Gross W.B. 1991. Colibacillosis, p.138-144. In: Calnek B.W., Barnes H.J., Beard C.W., Reid W.M. \& Yoder J.H.W. (Eds), Disease of Poultry. 9th ed. lowa State University Press, Ames.

Gross W.B. 1994. Diseases due to Escherichia coli in poultry, p.237259. In: Gyles C.L. (Ed.), Escherichia coli in Domestic Animals and Humans. CAB International, Wallingford, UK.

Gyimah J.E. \& Panigraphy B. 1988. Adhesin-receptor interactions mediating the attachment of pathogenic Escherichia coli to chicken tracheal epithelium. Avian Dis. 32:74-78.

Hafez H.B. \& Loehren U. 1990. Swollen head syndrome: clinical observations and serology in West Germany. Dtsch. Tierärztl. Wochenschr. 97:322-324.

Hardy G. 1975. Colicinogeny and related phenomena. Bacteriol. Rev. 39:464-515.

Hoschutzky H., Lottspeich F. \& Jann K. 1989. Isolation and characterization of the alpha-galactosyl-1,4-beta-galactosyl-specific adhesin ( $P$ adhesin) from fimbriated Escherichia coli. Infect. Immun. 57:76-81.

Hulton C.S., Higgins C.F. \& Sharp P.M. 1991. ERIC sequences: A novel family of repetitive elements in the genomes of Escherichia coli, Salmonella typhimurium and other enterobacteria. Mol. Microbiol. 5:825-834.

Janben T., Schwarz C., Preikschat P., Voss M., Phillip H.C. \& Wieler L.H. 2001. Virulence-associated genes in avian pathogenic Escherichia coli (APEC) isolated from internal organs of poultry having died from colibacillosis. Int. J. Med. Microbiol. 291:371-378.

Jann K. \& Jann B.J. 1977. Capsules of Escherichia coli, p.113-143. In: Sussman M. (Ed.), Escherichia coli: Mechanisms of virulence. Cambridge University Press, Cambridge, UK.

Johnson T.J., Giddings C.W., Horne S.M., Gibbs P.S., Wooley R.E., Skyberg J., Olah P., Kercher R., Sherwood J.S., Foley S.L. \& Nolan L. 2002. Location of increased serum survival gene and selected virulence traits on a conjugative $\mathrm{R}$ plasmid in an avian Escherichia coli isolate. Avian Dis. 46:342-352.

Johnson J.R., Murray A.C., Gajewsk A., Sullivan M., Snippes P., Kuskowisk M.A. \& Smith K.E. 2003. Isolation and molecular characterization of nalidixic acid resistant extraintestinal pathogenic Escherichia coli from retail chicken products. Antimicrob. Agents Chemother. 47:2161-2168.

Johnson T.J., Siek K.E., Johnson S.J. \& Nolan L.K. 2006. DNA sequence 
of a ColV plasmid and prevalence of selected plasmid-encoded virulence genes among avian Escherichia coli strains. J. Bacteriol. 188:745-758.

Johnson T.J., Kariyawasam S., Wannemuehler Y., Mangiamele P., Johnson S.J., Doetkott C., Skyberg J.A., Lynne A.M., Johnson J.R. \& Nolan L.K. 2007. The genome sequence of avian pathogenic Escherichia coli strain $\mathrm{O} 1: \mathrm{K} 1: \mathrm{H} 7$ shares strong similarities with human extraintestinal pathogenic E. coli genomes. J. Bacteriol. 189:.32283236.

Johnson T.J., Wannemuehler Y., Johnson S.J., Stell A.L., Doetkott C., Johnson J.R., Kim K.S., Spanjaard L. \& Nolan L.K. 2008. Comparison of extraintestinal pathogenic Escherichia coli from human and avian sources reveals a mixed subset representing potential zoonotic pathogens. Appl. Environ. Microbiol. Epub ahead of print.

Kallenius G., Mollby R., Svenson S.B., Winberg J. \& Hultberg H. 1980. Identification of a carbohydrate receptor recognized by uropathogenic Escherichia coli. Infection 8:288-293.

Kaper J.B., Nataro J.P. \& Mobley H.L. 2004. Pathogenic Escherichia coli. Nat. Rev. Microbiol. 2:123-140.

Karch H., Schubert S., Zhang D., Zhang W., Schmidt H., Olschlager T. \& Hacker J. 1999. A genomic island, termed high pathogenicity island, is present in certain non-O157 Shiga toxin-producing Escherichia coli clonal lineages. Infect. Immun. 67:5994-6001.

Kariyawasam S., Johnson T.J. \& Nolan L.K. 2006. The pap operon of avian pathogenic Escherichia coli strain $01: \mathrm{K} 1$ is located on a novel pathogenicity island. Infect. Immun. 74:744-749.

Kariyawasam S., Johnson T.J. \& Nolan L.K. 2008. Construction and characterization of type I fimbriae fimH deletion mutant from avian pathogenic Escherichia coli. Infect. Immun. 74:744-749.

Knöbl T., Baccaro M.R., Moreno A.M., Gomes T.A.T., Vieira M.A.M., Ferreira C.S. \& Ferreira A.J.P. 2001. Virulence properties of Escherichia coli isolated from ostriches with respiratory disease. Vet. Microbiol. 83:71-80

Kostakioti M. \& Stathopoulos C. 2004. Functional analysis of the Tsh autotransporter from an avian pathogenic Escherichia colistrain. Infect Imunn. 72:5548-5554.

La Ragione R.M. \& Woodward M.J. 2002. Virulence factor of Escherichia coli serotypes associated with avian colispticaemia. Res. Vet. Sci. 73:27-35.

La Ragione R.M., McLaren I., Foster G., Cooley W.A. \& Woodward M.J. 2002. Phenotypic and genotypic characterization of avian Escherichia coli 086:K61 isolates possessing a gamma-like intimin. Appl. Environ. Microbiol. 68:4932-4942.

Latham R.H. \& Stamm W.E. 1994. Role of fimbriated Escherichia coli in urinary tract infections in adult women: Correlation with localization studies. J. Infect. Dis. 149:835-840.

Li G., Laturnus C., Ewers C. \& Wieler L.H. 2005. Identification of genes required for avian Escherichia coli septicemia by signature-tagged mutagenesis. Infect. Imunn. 73:2818-2827.

Linggood M.A., Roberts M., Ford S., Parry S.H. \& Williams P.H. 1987. Incidence of the aerobactin iron uptake system among Escherichia coli isolates from infections of farm animals. J. Gen. Microbiol. 133:835-842.

Lynne A.M., Skyberg J.A., Logue C.M., Doetkott C., Foley S.L. \& Nolan L.K. 2007. Characterization of a series of transconjugant mutants of an avian pathogenic Escherichia coli isolate for resistance to serum complement. Avian Dis. 51: 771-776.

Marc D., Arne P., Bree A. \& Dho-Moulin M. 1998. Colonization ability and pathogenic properties of a fim- mutant of an avian strain of Escherichia coli. Res. Microbiol. 149:473-485.

Maurer J.J., Brown T.P., Steffens W.L. \& Thayer S.G. 1998. The occurrence of ambient temperature-regulated adhesions, curli, and the temperature-sensitive hemagglutinin Tsh among avian Escherichia coli. Avian Dis. 42:106-118.
McPeake S.J.W., Smuth J.A. \& Ball H.J. 2005. Characterization of avian pathogenic Escherichia coli (APEC) associated with colisepticaemia compared to faecal isolates from healthy birds. Vet. Microbiol. 110:245253.

Mellata M., Dho-Moulin M., Dozois C.M., Curtiss III R., Brown P.K., Arné P., Breé A., Desautels C. \& Fairbrother J.M. 2003. Role of virulence factor in resistance of avian pathogenic Escherichia coli to serum and in pathogenicity. Infect. Immun. 71:536-540.

Mokady D., Gophna U. \& Ron E.Z. 2005. Virulence factors of septicemic Escherichia coli strains. Int. J. Med. Microbiol. 295:455-462.

Mol O. \& Oudega B. 1996. Molecular and structural aspects of fimbriae biosinthesis and assemply in Escherichia coli. FEMS Microb. Rev. 19:25-52.

Moon H.W. 1990. Colonization factor antigens of Enterotoxigenic Escherichia coli in animals. Curr. Top. Microbiol. Immunol. 151:148-165.

Morley A.J. \& Thomson D.K. 1984. Swollen head syndrome in broiler chickens. Avian Dis. 28:238-243.

Moulin-Schouleur M., Répérant M., Laurent S., Brée A., Mignon-Grasteau S., Germon P., Rasschaert D. \& Schouler C. 2007. Extraintestinal pathogenic Escherichia coli strains of avian and human origin: link between phylogenetic relationships and common virulence patterns. J. Clin. Microbiol. 45: 3366-3376.

Moura A.C., Irino K. \& Vidotto M. 2001. Genetic variability of avian Escherichia coli strains evaluated by enterobacterial repetitive intergenic consensus and repetitive extragenic palindromic polymerase chain reaction. Avian Dis. 45:173-181.

Nagaraja K.V., Emery D.A., Jordan K.A., Sivanandan V., Newman J.A. \& Pomeroy B.S. 1984. Effect of ammonia on the quantitative clearance of Escherichia coli from lungs, air sacs, and livers of turkeys aerosol vaccinated against Escherichia coli. Am. J. Vet. Res. 45:392-395.

Nataro J.P. \& Kaper J.B. 1998 Diarrheagenic Escherichia coli. Clin. Microbiol. Rev. 11:142-201.

Ngeleka M., Kwaga J.K.P., White D.G., Whittam T.S., Riddell C., Goodhope R., Potter A.A. \& Allan B. 1996. Escherichia coli cellulitis in broiler chickens: Clonal relationships among strains and analysis of virulence-associated factor of isolates from diseased birds. Infect. Immun. 64:3118-3126.

Nunoya T., Tajima M., Izuchi T., Takahashi K., Otaki T., Nagasawa Y. \& Hakogi E. 1991. Pathology of a broiler disease characterized by the swollen head. J. Vet. Med. Sci. 53:347-349.

O‘Brien A.D., Thompson M.R., Cantey J.R. \& Formal S.B. 1977. Production of a Shigella dysenteriae-like toxin by pathogenic Escherichia coli. Abstracts Annu. Meet. Am. Soc. Microbiology, ASM, Washington, D.C. (Abstr.B103)

O'Brien A.D., LaVeck G.D., Thompson M.R. \& Formal S.B. 1982. Production of Shigella dysenteriae type 1-like cytotoxin by Escherichia coli. J. Infect. Dis. 146:763-769.

Okeke I.N., Scaletsky I.C.A., Soars E.H., MacFarlane L.R. \& Torres A.G. 2004. Molecular epidemiology of the iron utilization genes of enteroaggregative Escherichia coli. J. Clin. Microbiol. 42:36-44.

Olsén A., Arnqvist A., Hammar M., Sukupolvi S. \& Normak S. 1993. The RpSo sigma factor relieves H-NS-mediated transcriptional repression of $\operatorname{csgA}$, the subuniti gene of fribronectin-binding curli in Escherichia coli. Mol. Microb. 7:523-536.

Olsén A., Jonsson A. \& Normark S. 1989. Fibronectin binding mediated by a novel class of surface organelles on Escherichia coli. Nature 338:652-655.

Orskov I. \& Orskov F. 1985. Escherichia coli in extra-intestinal infections. J. Hyg. 95:551-575.

Overall Jr J.C. 1970. Neonatal bacterial meningitis. Analysis of predisposing factors and outcome compared with matched control subjects. J. Pediat. 76:499-511.

Oyentude O.O.F, Thomson R.G. \& Carlson H.C. 1978. Aerosol exposure 
of ammonia, dust and Escherichia coli in broiler chickens. Can. Vet. J. 19:187-193.

Parreira V.R. \& Gyles C.L. 2002. Shiga toxin genes in avian Escherichia coli. Vet. Microbiol. 87:341-352.

Parreira V.R. \& Gyles C.L. 2003. A novel pathogenicity island integrated adjacent to the thrW tRNA gene of avian pathogenic Escherichia coli encodes a vacuolating autotransporter toxin. Infect. Immun. 64:31183126.

Parreira V.R. \& Yano T. 1998. Cytotoxin produced by Escherichia coli isolated from chickens with swollen head syndrome (SHS). Vet. Microbiol. 62:11-119.

Pattison M., Chettle N., Randall C.J. \& Wyeth P.J. 1989. Observations on swollen head syndrome in broiler and broiler breeder chickens. Vet. Rec.125:229-231.

Pechere J.C. 1985. Facteurs microbiologiques de pathogénicité I' exemple de E. coli, p.7-52. In: Khoury S. (Ed.), Urologie Pathologie Infectieuse et Parasitaire. Masson, Paris.

Peeters J.E. 1994. Escherichia coli infections in rabbit, cats, dogs, gats and horses, p.261-283. In: Gyles C.L. (Ed.), Escherichia coli in Domestic Animals and Humans. CAB International, Wallingford, UK.

Pelludat C., Rakin A., Jacobi C.A., Schubert S. \& Heesmann J. 1998. The yersiniabactin biosynthetic gene cluster of Yersinia enterocolitica organization and siderophore dependent regulation. J. Bacteriol. 180:539-546.

Pennycott T.W., Ross H.M., McLaren I.M., Park A., Hopkins G.F. \& Foster G. 1998. Causes of death of wild-birds of the family Fringillidae in Britain. Vet. Rec. 143:155-158.

Pfaff-McDonough S.J., Home S.M., Giddings C.W., Ebert J.O., Doetkott C., Smith M.H. \& Nolan L.K. 2000. Complement resistance-related traits among Escherichia coli isolates from apparently healthy birds and birds with colibacillosis. Avian Dis. 44:23-33.

Picault J.P., Giraud P., Drouin P., Guittet M., Bennejean G., Lamande J., Toquin D. \& Gueguen C. 1987. Isolation of a TRTV-like virus from chickens with swollen-head syndrome. Vet. Rec. 121:135.

Pourbakhsh S.A., Dho-Moulin M., Breé A., Desautels C., MartineauDoize B. \& Fairbrother J.B. 1997. Localization of the in vivo expression of $P$ and $F 1$ fimbriae in chickens experimentally inoculated with pathogenic Escherichia coli. Microb. Pathog. 22:231-341.

Provence D.L. \& Curtiss III R. 1994. Isolation and characterization of a gene involved in hemagglutination by an avian pathogenic Escherichia coli strains. Infect. Immun. 62:1369-1380.

Rodriguez-Siek K.E., Giddings C.W., Doetkott C., Johnson T.J. \& Nolan L.K. 2005. Characterizing the APEC pathotype. Vet. Res. 36:241- 256.

Sabri M., Leveillé S. \& Dozois C.M. 2006. A SitABCD homologue from an avian pathogenic Escherichia coli strain mediates transport of iron and manganese and resistance to hydrogen peroxide. Microbiol. 152:745-758.

Sabri M., Caza M., Proulx J., Lymberopoulos M.H., Brée A., MoulinSchouleur M., Curtiss III R. \& Dozois C.M. 2008. Contribution of the SitABCD, MntH, and FeoB metal transporters to the virulence of avian pathogenic Escherichia coli 078 strain chi7122. Infect. Immun. 76: 601-611.

Schubert S., Rakin A., Karch H., Carniel E. \& Heesmannn J. 1998. Prevalence of the "high-pathogenicity island" of Yersinia species among Escherichia coli strains that are pathogenic to humans. Infect. Immun. 66:480-485.

Skyberg J.A., Johnson T.J. \& Nolan L.K. 2008. Mutational and transcriptional analyses of an avian pathogenic Escherichia coli ColV plasmid. BMC Microbiol. 29:8-24.

Shea J.E., Hensel M., Gleeson C. \& Holden D.W. 1996. Identification of a virulence locus encoding a second type III secretion system in Salmonella typhimurium. Proc. Natl Acad. Sci. USA 93:2593-2597.
Silveira W.D., Ferreira A., Brocchi M., Hollanda L.M., Castro A.F.P., Yamada A.T. \& Lancellotti M. 2002a. Biological characteristics and pathogenicity of avian Escherichia coli strains. Vet. Microbiol. 85:47-53.

Silveira W.D., Ferreira A., Lancellotti M., Barbosa I.A.G.C.D., Leite D.S., Castro A.F.P. \& Brocchi M. 2002b. Clonal relationships among avian Escherichia coli isolates determined by enterobacterial repetitive intergenic consensus (ERIC)-PCR. Vet. Microbiol. 89:323328.

Silveira W.D., Lancellotti M., Ferreira A., Solferini V.N., Castro A.F.P., Stehling E.G. \& Brocchi M. 2003. Determination of the clonal structure of avian Escherichia coli strains by isoenzyme and ribotyping analysis. J. Vet. Med. B, Infect. Dis. Vet. Public. HIth 50:63-69.

Smith H.W \& Gyles C.L. 1969. Escherichia coli enterotoxin. Vet. Res. 85(24):694-725.

Sokja W.J. 1965. Escherichia coli in Domestic Animals and Poultry. Commomw. Agric. Bureaux, Farnham Royal, Bucks, England, p.157168.

Stathopoulos C., Provence D.L. \& Curtiss III R. 1999. Characterization of the avian Escherichia coli hemagglutinin Tsh, a member the immunoglobulin A protease-type family of autotransporters. Infect. Immun. 67:772-781.

Stehling E.G., Yano T., Brocchi M. \& Silveira W.D. 2003. Characterization of a plasmid-encoded adhesion of an avian pathogenic Escherichia coli (APEC) strains isolated from a case of swollen head syndrome (SHS). Vet. Microbiol. 95:111-120.

Stocki S.L., Babiuk L.A., Rawlyk M.A., Potter A.A. \& Allan B.J. 2002. Identification of genomic differences between Escherichia coli strains pathogenic for poultry and E. coli K-12 MG1655 using suppression subtractive hybridization analysis. Microb. Pathog. 33:289-298.

Stordeur P., Marlier D., Blanco J., Oswald E., Biet F., Dho-Moulin M. \& Mainil J. 2002. Examination of Escherichia coli from poultry for selected adhesin genes important in disease caused by mammalian pathogenic E. coli. Vet. Microbiol. 84:231-241.

Valdivia R.H. \& Falkow S. 1996. Bacterial genetics by flow cytometry: Rapid isolation of Salmonella typhimurium acid-inducible promoters by differential fluorescence induction. Mol. Microbiol. 22:367-378.

Valvano M.A. 1992. Diphenylamine increases cloacin DF13 sensitivity in avian septicemic strains of Escherichia coli. Vet. Microbiol. 32:149161.

Versalovic J., Koeuth T. \& Lupski J.R. 1991. Distribution of repetitive DNA sequences in eubacteria and application to fingerprinting of bacterial genomes. Nucleic Acids Res. 19:6823-6831.

Waters V.L. \& Crosa J.H. 1991. Colicin V virulence plasmids. Microbiol. Rev. 55:437-450.

White D.G., Dho-Moulin M., Wilson R.A. \& Whittam T.S. 1993. Clonal relationships and variation in virulence among Escherichia coli strains of avian origin. Microb. Pathog. 14:399-409.

Williams P.H. \& Griffiths E. 1992. Bacterial transferrin receptors-structure, function and contribution to virulence. Med. Microbiol. Immunol. 181:301-322.

Williams P.H. 1979. Novel iron uptake system specified by ColV plasmids: an important component in the virulence of invasive strains of Escherichia coli. Infect. Immun. 26:925-932.

Wooley R.E. \& Blue J.L. 1976. Bacterial isolations from canine and feline urine. Mod. Vet. Pract. 57:535-538.

Wooley R.E., Gibbs P.S., Brown T.P., Glisson J.R., Steffens W.L., Maurer J.J. 1998. Colonization of the chicken trachea by an avirulent avian Escherichia coli transformed with plasmid pHK11. Avian Dis. 42:194198.

Wray C. \& Woodward M.J. 1997. Escherichia coli infections in farm animals, p.49-84. In: Sussman M. (Ed.), Escherichia coli Mechanisms of Virulence. Cambridge University Press, Cambridge, UK. 